\title{
Evolutionary convergence of the patterns of international research collaborations across scientific fields
}

Citation for published version (APA):

Wang, L., \& Coccia, M. (2015). Evolutionary convergence of the patterns of international research collaborations across scientific fields. UNU-MERIT. UNU-MERIT Working Papers No. 011

Document status and date:

Published: 01/01/2015

\section{Document Version:}

Publisher's PDF, also known as Version of record

\section{Please check the document version of this publication:}

- A submitted manuscript is the version of the article upon submission and before peer-review. There can be important differences between the submitted version and the official published version of record. People interested in the research are advised to contact the author for the final version of the publication, or visit the DOI to the publisher's website.

- The final author version and the galley proof are versions of the publication after peer review.

- The final published version features the final layout of the paper including the volume, issue and page numbers.

Link to publication

\footnotetext{
General rights rights.

- You may freely distribute the URL identifying the publication in the public portal. please follow below link for the End User Agreement:

www.umlib.nl/taverne-license

Take down policy

If you believe that this document breaches copyright please contact us at:

repository@maastrichtuniversity.nl

providing details and we will investigate your claim.
}

Copyright and moral rights for the publications made accessible in the public portal are retained by the authors and/or other copyright owners and it is a condition of accessing publications that users recognise and abide by the legal requirements associated with these

- Users may download and print one copy of any publication from the public portal for the purpose of private study or research.

- You may not further distribute the material or use it for any profit-making activity or commercial gain

If the publication is distributed under the terms of Article 25fa of the Dutch Copyright Act, indicated by the "Taverne" license above, 


\section{UNITED NATIONS \\ UNIVERSITY}

UNU-MERIT

\section{Working Paper Series}

\section{\#2015-011}

Evolutionary convergence of the patterns of international research collaborations across scientific fields

Mario Coccia and Lili Wang

Maastricht Economic and social Research institute on Innovation and Technology (UNU-MERIT) email: info@merit.unu.edu | website: http://www.merit.unu.edu

Maastricht Graduate School of Governance (MGSoG)

email: info-governance@maastrichtuniversity.nl | website: http://mgsog.merit.unu.edu

Keizer Karelplein 19, 6211 TC Maastricht, The Netherlands

Tel: (31) (43) 388 4400, Fax: (31) (43) 3884499 


\section{UNU-MERIT Working Papers}

ISSN 1871-9872

Maastricht Economic and social Research Institute on Innovation and Technology, UNU-MERIT

\section{Maastricht Graduate School of Governance}

MGSoG

UNU-MERIT Working Papers intend to disseminate preliminary results of research carried out at UNU-MERIT and MGSoG to stimulate discussion on the issues raised. 


\title{
EVOLUTIONARY CONVERGENCE OF THE PATTERNS OF INTERNATIONAL RESEARCH COLLABORATIONS ACROSS SCIENTIFIC FIELDS ${ }^{1}$
}

\author{
Mario COCCIA ${ }^{\text {abc }}$ \& Lili WANG ${ }^{\mathrm{b}}$ \\ ${ }^{a}$ CNR -- National Research Council of Italy, \\ ${ }^{\mathrm{b}}$ United Nations University -The Maastricht Economic and Social Research Institute \\ on Innovation and Technology (UNU-MERIT) \\ ${ }^{c}$ Arizona State University-School of Public Affairs \\ *Address: UNU-MERIT \\ Keizer Karelplein 19,6211 TC Maastricht-The Netherlands \\ E-mail: mario.coccia@ircres.cnr.it; wang@merit.unu.edu
}

\begin{abstract}
Frame and Carpenter (1979) analysed the pattern of international research collaboration among scientific fields in 1970s. Starting from this pioneering work, this paper investigates international collaborations over 1997-2012 and compares the critical results with earlier studies to detect the evolution of collaboration patterns in different scientific fields. Empirical analysis supports two vital findings, given by: a) a relatively stable structure of international research collaborations over time across different scientific fields; $b$ ) a convergent process of collaboration patterns between theoretical and applied research fields. One important determinant of the latter result might be due to the increasing interdisciplinary nature of research fields that supports the convergence between basic and applied sciences.
\end{abstract}

Keywords: Scientific Fields, Research Collaboration, Science Evolution, Co-authorship, Copublishing, Interdisciplinary, Convergence.

JEL classification: O31; O39; O10; N00; N31; N33.

\footnotetext{
${ }^{1}$ Mario Coccia gratefully acknowledges financial support from United Nations University -The Maastricht Economic and Social Research Institute on Innovation and Technology (Contract ID 606U U-04 76) where this research was conducted while he was visiting scholar in 2014. We thank Paula Stephan and Bart Verspagen for fruitful comments and suggestions. The usual disclaimer applies.
} 


\section{Introduction}

International scientific collaboration has received much attention by scholars since it is a main feature of scientific communities across different research fields ${ }^{2}$. Research collaboration can take place at different levels: individual researchers, research teams/labs, departments, universities, sectors and nations (Katz and Martin, 1997). In general, by sharing knowledge and data, research collaboration improves labour efficiency in the scientific production process. Katz and Martin (1997, p. 15) claim that research collaboration is: "a crossfertilization of ideas which may ... generate new insights or perspectives that individuals, working on their own, would not have grasped (or grasped as quickly)”. Research collaborations are a rational division of scientific labour to increase the efficiency of subjects/organisations in order to achieve fruitful results in shorter time (Coccia, 2014a).

De Solla Price (1963) was a pioneer in measuring collaborations via multi-authored articles. These have been widely recognised as forming the most useful and apt scientific indicator for measuring and evaluating research collaborations ( $c f$. de Solla Price and Beaver, 1966; van Raan, 1988; 1998; Egghe, 1991; Luukkonen et al., 1993; Stokes and Hartley, 1989; Glänzel and De Lange, 1997).

In economics of science, it is crucial to analyse patterns of international collaboration across different scientific disciplines in order to detect evolutionary trends of scientific fields ${ }^{3}$. Frame and Carpenter (1979) have analysed, considering 1973 data, the patterns of international research collaborations of some scientific fields. Starting from this pioneering work, the purpose of this paper is to investigate the recent international co-authorships of research institutions and to compare the results with earlier studies in order to detect vital characteristics concerning the basic structure and evolutionary dynamics of different scientific fields over time.

\footnotetext{
${ }^{2}$ Cf. Zitt et al., 2000; Schubert and Braun, 1990; Peters and Van Raan, 1989; Beaver, 2001; Cummings and Kiesler, 2005; cf. Hackett, 2005; Lee and Bozeman, 2005; Presser, 1980.

${ }^{3}$ Cf. de Solla Price, 1963; 1986; Kuhn, 1970; Beaver and Rosen, 1978; Luukkonen et al., 1992; Frame, 1979; Frame et al., 1977; Inhaber, 1977; Stephan, 1996.
} 


\section{Theoretical background and related studies}

Beaver and Rosen (1978) argue that scientific collaboration is not a modern feature of scientific fields, since the early collaborations appeared during the scientific revolution of the $17^{\text {th }}$ and $18^{\text {th }}$ centuries. In fact, Beaver and Rosen (1978, pp. 73-74) consider a historical bibliography of papers before 1800 and show that the earliest collaborative papers were from 1665 by joint researches among Hooke, Cassini and Boyle. According to these scholars, the beginning of scientific collaboration represents a response to the "professionalization of science" (Beaver and Rosen, 1978, p. 65).

Puuska et al. (2014) argue that in current economies both international and domestic copublishing have increased during the last decades in all scientific fields. Georghiou (1998, pp. 613-616) shows a huge increase in the number and share of collaborative papers between the European Union and other industrialised countries (e.g. Australia, Canada, Japan, New Zealand, Korea and USA) over 1985-1995. Modern society endows international collaboration with a new feature of scientific vitality.

Various motives for performing collaborative research have been discussed, including access to high-tech equipment or facilities, sharing skills and specific materials, as well as enhancing scientific visibility and recognition (Beaver and Rosen, 1978, p. 70). In recent decades, scientific collaboration has also increased due to the complexity and high cost of scientific research concerning 'big science' (Hand, 2010; Katz and Martin, 1997; De Solla Price, 1986) as well as to the growing importance of new multidisciplinary fields (Jeong et al., 2011; Van Leeuwen and Tijssen, 1993). In addition, the rapid growth of Information and Communication Technologies (ICTs), the improvement of transportation technology together with the reduction of cost have also greatly facilitated scientific communication and "the rise of research network" (Adams, 2012; cf. Katz and Martin, 1997). Laudel (2001) argues that most research collaborations start with a face-to-face meeting in fruitful environments such as conferences, congresses, symposium, research labs, etc. (cf. Bozeman, 2004: Latour and Woolgar, 1979).

International collaboration intensity tends to vary greatly among different scientific disciplines, with the highest frequency of co-authored scientific research in astronomy. In fact, joint research in astronomy seems to be driven by the necessity of sharing equipment and data in observatories (Beaver and Rosen, 1978). Frame and Carpenter (1979), using data from 
the 1973 Science Citation Index concerning journals in all scientific fields and a sample of key countries, show the highest international collaboration intensity in earth \& space sciences and physics, but the lowest intensity is in engineering. Luukkonen et al. (1992), considering data of the year 1983, show similar results: higher collaborations are also in earth and space science, mathematics and physics.

In general, the analysis of the patterns of international research collaboration is of great scientific interest to understand the nature and evolution of different scientific fields. This study tackles this issue and aims to pinpoint vital characteristics of scientific collaboration that support the structure and evolutionary patterns of research fields.

\section{Data and study design}

\subsection{Data collection}

This study focuses on international research collaborations in scientific fields based on article counts from the set of journals covered by the Science Citation Index (SCI) and Social Sciences Citation Index (SSCI) in the dataset by National Science Foundation (2014)-National Center for Science and Engineering Statistics, special tabulations from Thomson Reuters (2013). In particular, this study considers published articles in all scientific fields classified by co-authorship attribute (total articles with domestic institutions only; Total articles with international institutions), in the period 1997-2012. Articles with international institutions are counts of articles with one or more institutional addresses outside the country.

The research fields of the study are listed in Appendix A, whereas the international coauthored papers across scientific fields are analysed considering a sample of forty countries (listed in Appendix B). Scientific publications produced by these forty countries accounted for $97 \%$ of the worldwide total output in the studied period. This study also considers a subset of 11 Western countries and 9 research fields in order to provide results comparable with the study by Frame and Carpenter (1979). The 11 countries yielded in the 1996 about $65 \%$ of the worldwide production of scientific articles, and this share declined to $51 \%$ in 2011 likely due to the fast growth of scientific production by China. 


\subsection{Methodology}

First of all, this study computes per scientific field $i$ the total intensity of internationally coauthored papers (ICP ${ }_{i t)}$ during the period 1997 - 2012. The formula is given by:

$$
I C P_{i t}=\frac{\text { Co-authored articles with international institutions }}{i t}
$$

Where $i=$ scientific field ( $c f$. Appendix A); $t=1997, \ldots, 2012$.

Dynamics of collaboration patterns. The temporal evolution of collaboration patterns across scientific fields is examined by regression analysis. Ordinary Least Squares (OLS) is applied to capture the vital relationships between dependent variable - Intensity of international collaborations per research field $\left(\mathrm{ICP}_{i t}\right)$ - and explanatory variable time $t$. Coefficients of regression of estimated relationships assess how international research collaborations change over time in scientific fields.

Structure of collaboration patterns. The structure of scientific fields is analysed by the hierarchical clustering, by means of squared Euclidean distance and the method of Ward. This technique detects the groups of scientific fields that have similar intensities of international co-authored papers over 1997-2012.

Comparison of collaboration patterns with previous studies. The results of this study are compared with earlier studies by Frame and Carpenter (1979) and Luukkonen et al. (1992). To put all the $\mathrm{ICP}_{i t}$ values from different studies in a comparable framework, we standardise the intensities as follows:

$$
Z_{i t}=\frac{I C P_{i t}-\mu_{t}}{\sigma_{t}}
$$

where

$\mathrm{Z}_{i t}=$ Standardised value of $\mathrm{ICP}_{i t}$

$I C P_{i t}=$ Intensity of internationally co-authored papers per research field $i$ at year $t$

$\mu_{t}=$ the arithmetic mean of the ICP in all fields at year $t$

$\sigma_{t}=$ the standard deviation of the ICP in all fields at year $t$ 
The absolute value of $Z_{i t}$ represents the distance between the raw score $I C P_{i t}$ and the mean in unit of the standard deviation. $Z_{i t}$ is negative when the raw score is below the mean, positive when it is above. A zero value of $Z_{\text {it }}$ indicates that the raw intensity is equal to the arithmetic mean.

In addition, this study applies a non-parametric measure of association (Spearman's rho $\rho$ ) and Pearson's coefficients of correlation to analyse the ranking and distribution of the intensity of internationally co-authored papers among scientific disciplines over time $\left(\mathrm{ICP}_{i t}\right.$ per research field $i$ at $t$ ).

Spearman's rho $\rho$ for a sample of size $n$ is:

$$
\rho=1-\frac{6 \sum d_{i}^{2}}{n\left(n^{2}-1\right)}
$$

where $d_{i}=x_{i}-y_{i}$ is the difference between ranks, and $n$ is the size of sample.

The Pearson's correlation coefficient is $r$ :

$$
r=\frac{\sigma_{x y}}{\sigma_{x} \sigma_{y}}
$$

$\sigma_{\mathrm{xy}}$ is covariance between $\mathrm{X}$ and $\mathrm{Y}, \sigma_{\mathrm{x}}$ and $\sigma_{\mathrm{y}}$ are standard deviation.

Dynamics of collaboration patterns. To examine the relative variability of collaboration intensity in different fields over time, this study also applies the Coefficient of Variation $\left(\mathrm{CV}_{\mathrm{t}}\right)$ given by:

$$
C V_{t}=\frac{\mu_{t}}{\sigma_{t}}
$$

where:

$\mathrm{CV}_{t}$ is the coefficient of variation at year $t$

$\mu_{t}$ is the arithmetic mean of the collaboration intensities in all research fields at year $t$

$\sigma_{t}$ is the standard deviation of collaboration intensities in all research fields at year $t$

The comparison of coefficient variation values in different time periods reveals the dynamics of the degree of variation. An increasing $\mathrm{CV}$ indicates that the collaboration performance across all fields is divergent, whereas a decreasing $\mathrm{CV}$ shows a convergence trend.

Statistical analyses are performed by Statistics Software SPSS $®$ version 15.0. 


\section{Empirical analyses}

\subsection{Trends of international research collaboration intensity}

Figure 1 shows the growing trend of international collaboration intensities in different scientific disciplines during the period 1997 - 2012. Astronomy is on the top; its international collaboration intensity increased from 68 per cent in 1997 to 83 per cent in 2012. In spite of their steadily rising values, Medicine, Chemistry and Engineering have relatively lower intensities. The collaboration patterns are analysed by a regression analysis to measure the rate of growth over time per research field.

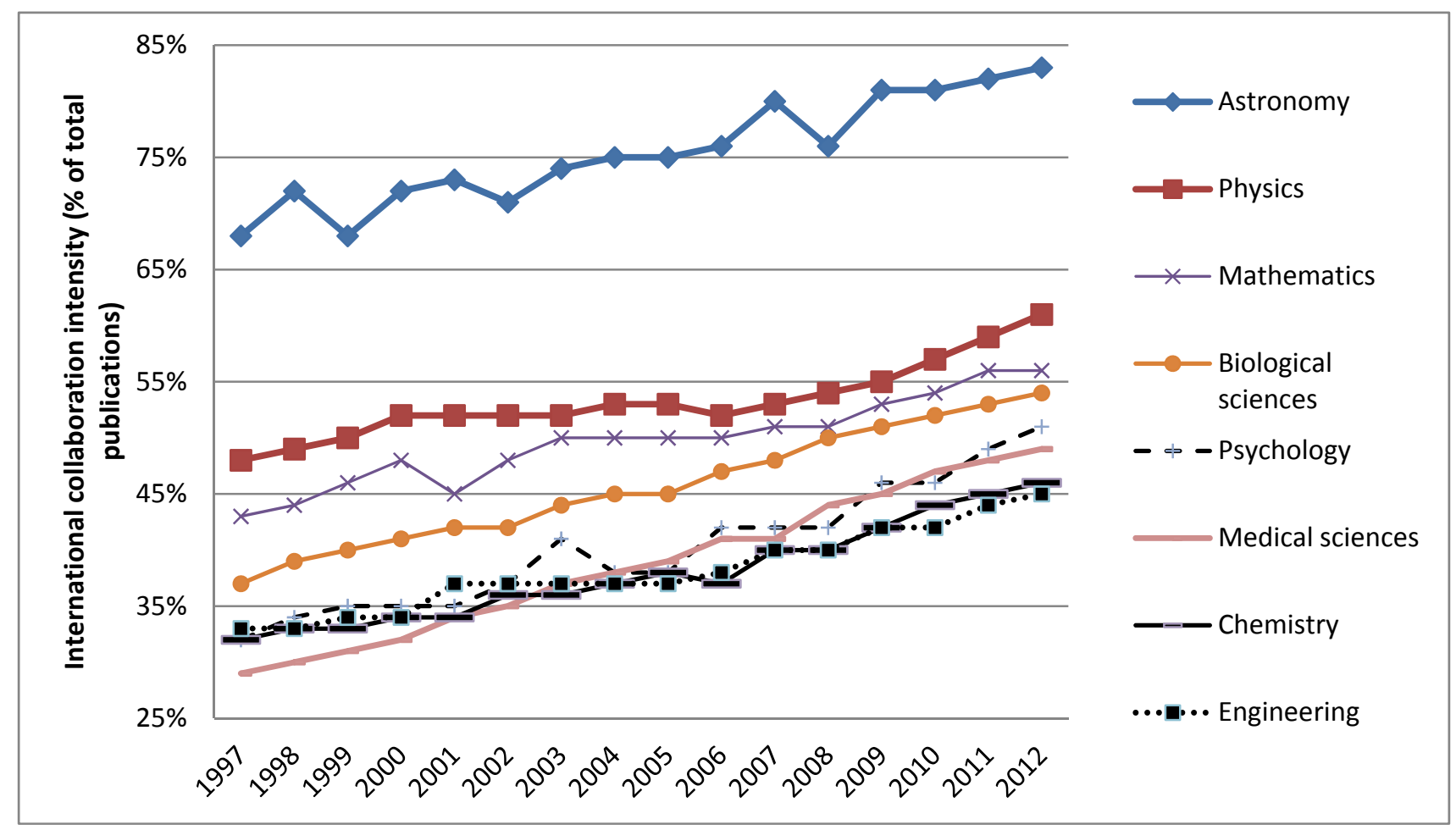

Figure 1: Trend of the intensity of international collaborations by scientific field

Note: This figure is plotted based on the absolute value of intensity

Table 1 shows the estimated relationships by linear regression analysis over 1997-2012. The results also show a strong (probabilistic) explanatory power of linear models: significance of $\beta$ coefficients is $p \leq 0.001$ and $\mathrm{R}^{2}$ has high values. 
Table 1: OLS regressions in scientific fields

\begin{tabular}{|c|c|c|c|c|}
\hline Research Fields & $\begin{array}{r}\text { Constant } \\
\alpha \\
\text { (St. Err.) }\end{array}$ & $\begin{array}{r}\text { Coefficient } \\
\beta \\
\text { (St. Err.) }\end{array}$ & $\begin{array}{r}R^{2} \\
\text { (St. Err. } \\
\text { of the } \\
\text { Estimate) }\end{array}$ & $\begin{array}{r}F \\
\text { (sign.) }\end{array}$ \\
\hline \multirow[t]{2}{*}{ Astronomy } & -18.436 & $0.010 * * *$ & 0.894 & 127.12 \\
\hline & $(1.702$ & $(0.001)$ & $(0.016)$ & $(0.00)$ \\
\hline \multirow[t]{2}{*}{ Physics } & -12.674 & $0.007 * * *$ & 0.832 & 75.339 \\
\hline & $(1.521)$ & $(0.001)$ & $(0.014)$ & $(0.00)$ \\
\hline \multirow[t]{2}{*}{ Geosciences } & -21.719 & $0.011 * * *$ & 0.982 & 839.226 \\
\hline & $(0.767)$ & $(0.000)$ & $(0.007)$ & $(0.00)$ \\
\hline \multirow[t]{2}{*}{ Mathematics } & -15.451 & $0.008 * * *$ & 0.925 & 185.627 \\
\hline & $(1.171)$ & $(0.001)$ & $(0.011)$ & $(0.00)$ \\
\hline \multirow[t]{2}{*}{ Computer Sciences } & -14.386 & $0.007 * * *$ & 0.649 & 28.743 \\
\hline & $(2.771)$ & $(0.001)$ & $(0.025)$ & $(0.00)$ \\
\hline \multirow[t]{2}{*}{ Biological Sciences } & -21.770 & $0.011 * * *$ & 0.991 & 1571.727 \\
\hline & $(0.561)$ & $(0.000)$ & $(0.005)$ & $(0.00)$ \\
\hline \multirow[t]{2}{*}{ Psychology } & -22.502 & $0.011 * * *$ & 0.923 & 180.041 \\
\hline & $(1.707)$ & $(0.001)$ & $(0.016)$ & $(0.00)$ \\
\hline \multirow[t]{2}{*}{ Medical Sciences } & -27.322 & $0.014 * * *$ & 0.995 & 2761.25 \\
\hline & $(0.527)$ & $(0.000)$ & $(0.005)$ & $(0.00)$ \\
\hline \multirow[t]{2}{*}{ Other Life Sciences } & -20.295 & $0.010 * * *$ & 0.773 & 52.087 \\
\hline & $(2.867)$ & $(0.001)$ & $(0.026)$ & $(0.00)$ \\
\hline \multirow[t]{2}{*}{ Chemistry } & -18.044 & $0.009 * * *$ & 0.951 & 293.231 \\
\hline & $(1.076)$ & $(0.001)$ & $(0.010)$ & $(0.00)$ \\
\hline \multirow[t]{2}{*}{ Engineering } & -15.006 & $0.008 * * *$ & 0.942 & 246.176 \\
\hline & $(0.981)$ & $(0.000)$ & $(0.009)$ & $(0.00)$ \\
\hline \multirow[t]{2}{*}{ Agricultural Sciences } & -20.102 & $0.01 * * *$ & 0.957 & 336.603 \\
\hline & $(1.117)$ & $(0.001)$ & $(0.010)$ & $(0.00)$ \\
\hline \multirow[t]{2}{*}{ Social Sciences } & -17.167 & $0.009 * * *$ & 0.846 & 83.379 \\
\hline & $(1.918)$ & $(0.001)$ & $(0.018)$ & $(0.00)$ \\
\hline
\end{tabular}

Note: 1) Dependent variable: Intensity of internationally co-authored papers; Explanatory variable $t ; 2){ }^{* * *}$ Coefficients $\beta$ are all significant at $p \leq 0.001$; Explanatory variable is the time $T=1997-2012$. 


\subsection{Structure of international research collaborations across scientific fields}

The structure of collaboration pattern across scientific disciplines is examined by hierarchical clustering. Figure 2 shows three basic groups of the under studied 13 scientific fields:

\section{Group 1: Astronomy}

Group 2: Physics, Mathematics, Computer, Biological and Geo Sciences

Group 3: Engineering, Chemistry, Medicine, Psychology, Social sciences, Agricultural Science and other Life Sciences
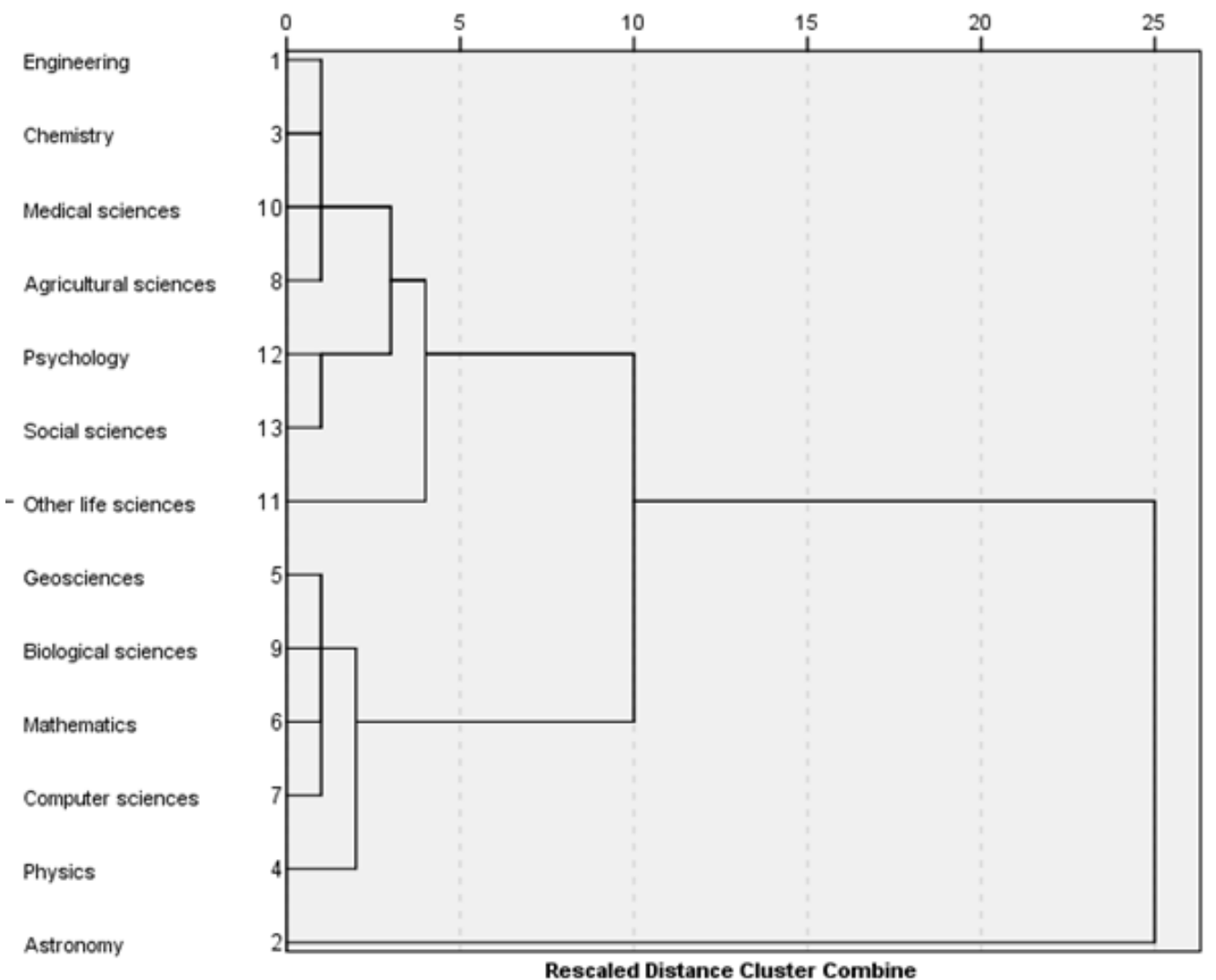

\section{Figure 2: Similarity clusters of the intensity of international collaborations}

Note: 1) Hierarchical clusters are performed using Ward's method and applying squared Euclidean distance. 2) Period: 1997-2012.

The main characteristics of these three groups are as follows.

First, theoretical fields (group 1 and 2) have a higher intensity of international collaborations over time (see also in Fig. 1). Research in these fields focuses mainly on general scientific and technological problems.

Second, contrary to theoretical fields, applied sciences (in particular engineering, human and social sciences, i.e. group 3), which focus on local and specific technical problems (contextdependent issues), have lower international collaboration intensity. This result is in line with 
the argument by Allen et al. (1979, p. 695): "Science may be said universal. . . Technology [applied sciences], on the other hand, is not universal".

Third, astronomy seems to be an outlier, with the largest distance from other research fields in terms of collaboration pathway.

\subsection{Comparison of results (with studies by Frame and Carpenter, 1979 and Luukkonen et al., 1992)}

Despite the general acceleration in scientific collaboration intensity of all research fields, as shown in Figure 1, an interesting observation is that Astronomy, Physics and Mathematics tend to have higher intensity throughout the period 1997-2012; vice versa Chemistry, Engineering and Psychology have lower intensity. In order to further investigate the long-run evolution of international collaboration patterns among research fields, this study combines its results with those by Frame and Carpenter (1979) and Luukkonen et al. (1992). Standardisation $Z$ is applied to all collaboration intensities in order to make them comparable (see Methodology section for details). Results of the standardisation are reported in Table 2 and Table $\mathrm{C} 1$ in Appendix. 
Table 2: Intensity of international collaborations per key scientific fields (comparison of results from different studies)

\begin{tabular}{|c|c|c|c|c|c|}
\hline \multirow[b]{2}{*}{ Subject } & \multirow{2}{*}{$\begin{array}{c}\begin{array}{r}\text { Frame and Carpenter } \\
(1978, \text { p. 484) }\end{array} \\
1973\end{array}$} & \multicolumn{2}{|c|}{$\begin{array}{l}\text { Luukkonen et al. } \\
(1992, \text { p. 118) }\end{array}$} & \multicolumn{2}{|c|}{ THIS STUDY } \\
\hline & & 1973 & 1983 & $\begin{array}{c}1997-2012 \\
\text { (40 countries) }\end{array}$ & $\begin{array}{c}1997-2012 \\
\text { (11 countries) }\end{array}$ \\
\hline & $\%$ & $\%$ & $\%$ & $\%$ & $\%$ \\
\hline Astronomy & 4.45 & 5.38 & 11.8 & 77.1 & 78.8 \\
\hline Physics & 4.23 & 4.39 & 9.45 & 54.0 & 56.6 \\
\hline Mathematics & 3.75 & 5.47 & 10.78 & 50.5 & 52.0 \\
\hline Biomedical Research & 2.63 & 3.51 & 6.93 & n.a. & n.a. \\
\hline Chemistry & 2.03 & 2.42 & 5.37 & 47.9 & 40.6 \\
\hline Biology & 1.68 & 3.01 & 5.84 & 46.4 & 46.1 \\
\hline Psychology & 1.66 & n.a. & n.a. & 41.7 & 34.9 \\
\hline Clinical Medicine & 1.61 & 2.47 & 4.77 & 39.8 & 38.7 \\
\hline Engineering & 1.46 & 2.04 & 5.16 & 38.9 & 39.4 \\
\hline \multicolumn{6}{|c|}{ Standardisation of results by $Z$ per year } \\
\hline & $\begin{array}{r}\text { Frame and Carpenter } \\
(1978, \text { p. 484) }\end{array}$ & $\begin{array}{r}\text { Luukk } \\
(199\end{array}$ & $\begin{array}{l}\text { et al. } \\
118)\end{array}$ & THIs & UDY \\
\hline \multirow[t]{2}{*}{ Subject } & 1973 & 1973 & 1983 & $\begin{array}{c}1997-2012 \\
\text { (40 countries) }\end{array}$ & $\begin{array}{c}1997-2012 \\
\text { (11 countries) }\end{array}$ \\
\hline & $\%$ & $\%$ & $\%$ & $\%$ & $\%$ \\
\hline Astronomy & 1.52 & 1.33 & 1.55 & 2.24 & 2.13 \\
\hline Physics & 1.34 & 0.60 & 0.70 & 0.36 & 0.58 \\
\hline Mathematics & 0.94 & 1.40 & 1.18 & 0.08 & 0.25 \\
\hline Biomedical Research & 0.02 & -0.06 & -0.21 & n.a. & n.a. \\
\hline Chemistry & -0.48 & -0.86 & -0.77 & -0.13 & -0.54 \\
\hline Biology & -0.77 & -0.43 & -0.60 & -0.26 & -0.16 \\
\hline Psychology & -0.79 & -2.66 & -2.71 & -0.64 & -0.94 \\
\hline Clinical Medicine & -0.83 & -0.83 & -0.99 & -0.79 & -0.68 \\
\hline Engineering & -0.95 & -1.15 & -0.85 & -0.86 & -0.63 \\
\hline
\end{tabular}

Note: 1) Detailed description of $\mathrm{Z}$ standardisation is provided in the methodology section. Data are standardised within the set of year (or period), i.e. $\mathrm{t}=1973$, 1983, etc.; "n.a." means no data available.

2) Refer to Appendix C for more details.

Table 2 shows the comparison of the results of this study with those by Frame and Carpenter (1979) and Luukkonen et al. (1992). Although these studies were performed in periods with different socio-economic and technological contexts (i.e. in 1973, 1983 and 1997-2012 period), the results have a great degree of similarity. Patterns of international research collaboration concerning scientific fields seem to have a rather stable structure in their evolutionary pathways. In other words, some disciplines persist with a higher intensity of international re- 
search collaboration over time (e.g. Physics), vice versa Engineering and Clinical medicine. Figure 3 synthetises this similarity of results over a time span of about 40 years.

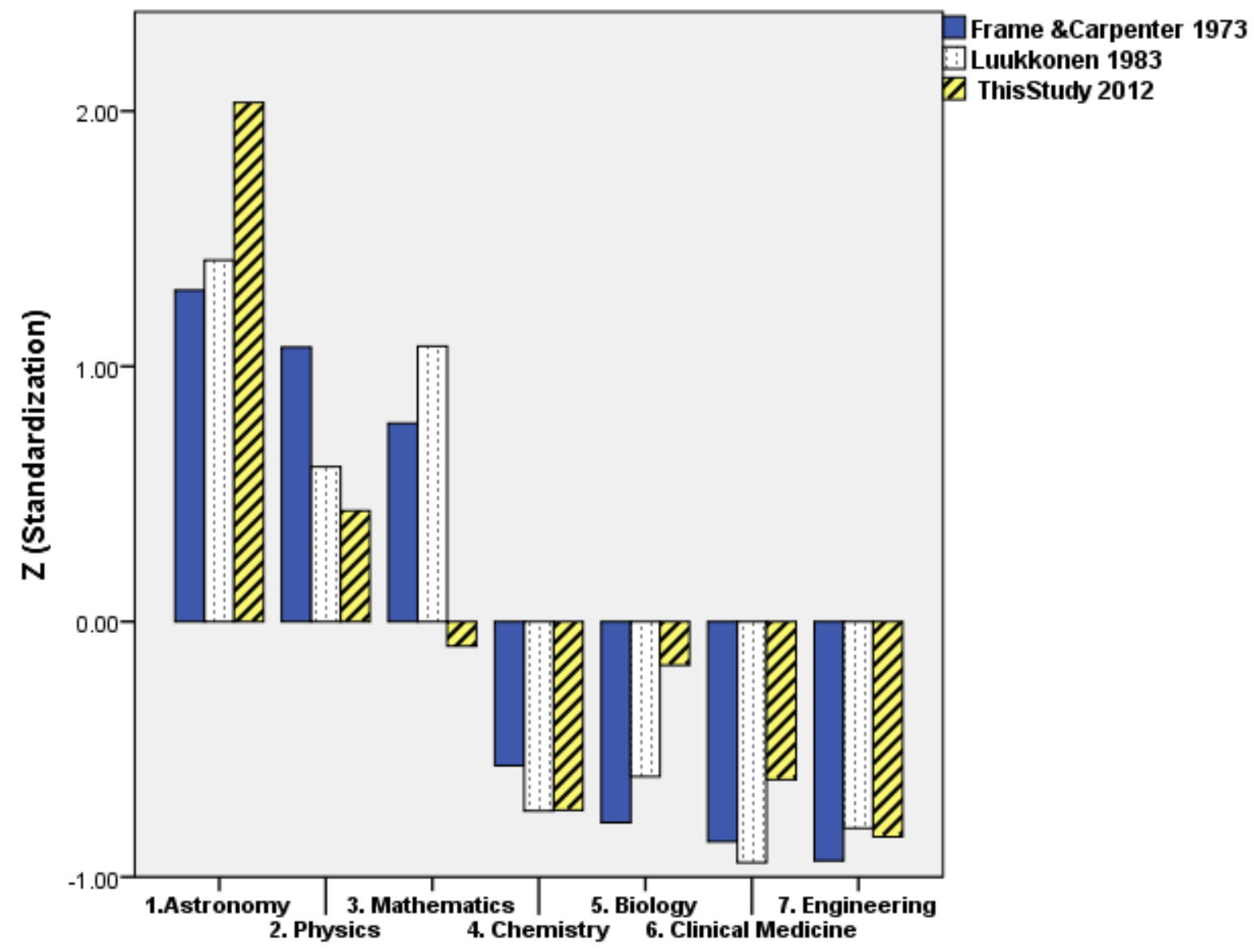

Figure 3: Intensity of collaboration (standardised Z) among three studies performed in different time period.

Spearman' rho $\rho$ and Pearson's coefficients of correlation $r$ between results of this paper and previous studies rigorously show that both have high positive significant values (Table 3 ). This confirms that evolutionary pathways of international collaboration in different scientific fields remained unchanged in their temporal trajectories. In particular, Astronomy and Physics (representatives of theoretical research fields) had high intensity of international collaborations in 1973, 1983 and this tendency continued over 1997-2012, whereas Engineering (a field of applied research to develop technology) had lower international collaborations in 1973, 1983 and this continued over 1997-2012 as well. 
Table 3: Correlation between this study and previous ones

\begin{tabular}{lrrr}
\hline & $\begin{array}{c}\text { Frame \& Carpenter } \\
\text { Data 1973 }\end{array}$ & $\begin{array}{c}\text { Luukkonen et al. } \\
\text { Data 1973 }\end{array}$ & $\begin{array}{c}\text { Luukkonen et al. } \\
\text { Data 1983 }\end{array}$ \\
\hline Spearman's rho $\rho$ & & & \\
Correlation Coefficient & $1.000^{* * *}$ & $0.786^{* *}$ & $0.893^{* * *}$ \\
Sig. (2-tailed) & 0.0 & 0.036 & 0.007 \\
N & 8 & 7 & 7 \\
& & & \\
Pearson's Correlation $r$ & $0.827^{* *}$ & $0.763^{* *}$ & $0.826^{* *}$ \\
Sig. (2-tailed) & 0.011 & 0.046 & 0.022 \\
N & 8 & 7 & 7 \\
\hline
\end{tabular}

Note: 1$){ }^{* * *}$ Correlation is significant at the 0.01 level (2-tailed);** Correlation is significant at the 0.05 level (2-tailed). 2) This study covers data over $1997-2012$ period.

These findings reveal that, despite the fast growth of international co-authorships in different disciplines, the structure of collaborative research across scientific fields in their evolutionary pathways tends to be unchanged (stability of scientific structure). That is, the rank of the intensity of collaboration patterns across research fields in 2012 is similar to that of 40 years ago.

\subsection{Evolutionary convergent process of international research collaboration patterns be- tween theoretical and applied sciences}

This study has standardised the collaboration intensity across disciplines to put various results in a comparative analytical framework (see Table 2 and Table $\mathrm{C} 1$ in Appendix C). Figure 4 displays the evolutionary dynamics of collaboration patterns across research fields. Although the structure of collaborative science is unchanged (Astronomy and Physics were the research fields with the highest intensity of international collaborations in 1973, 1983 and they continued this tendency also during 1997-2012, whereas the Engineering and Clinical medicine had lower intensity in 1973, 1983 as well as over 1997-2012 period), results in Fig. 4 show that, except the outlier of Astronomy pathway, the gap between all other fields has been reducing, tremendously. This indicates a critical convergent process of international collaboration pathways across different research fields. This result demonstrates that external factors are affecting pathways of scientific collaboration performance in various fields, despite they do not dramatically change the intrinsic nature and basic collaboration structure of science. 


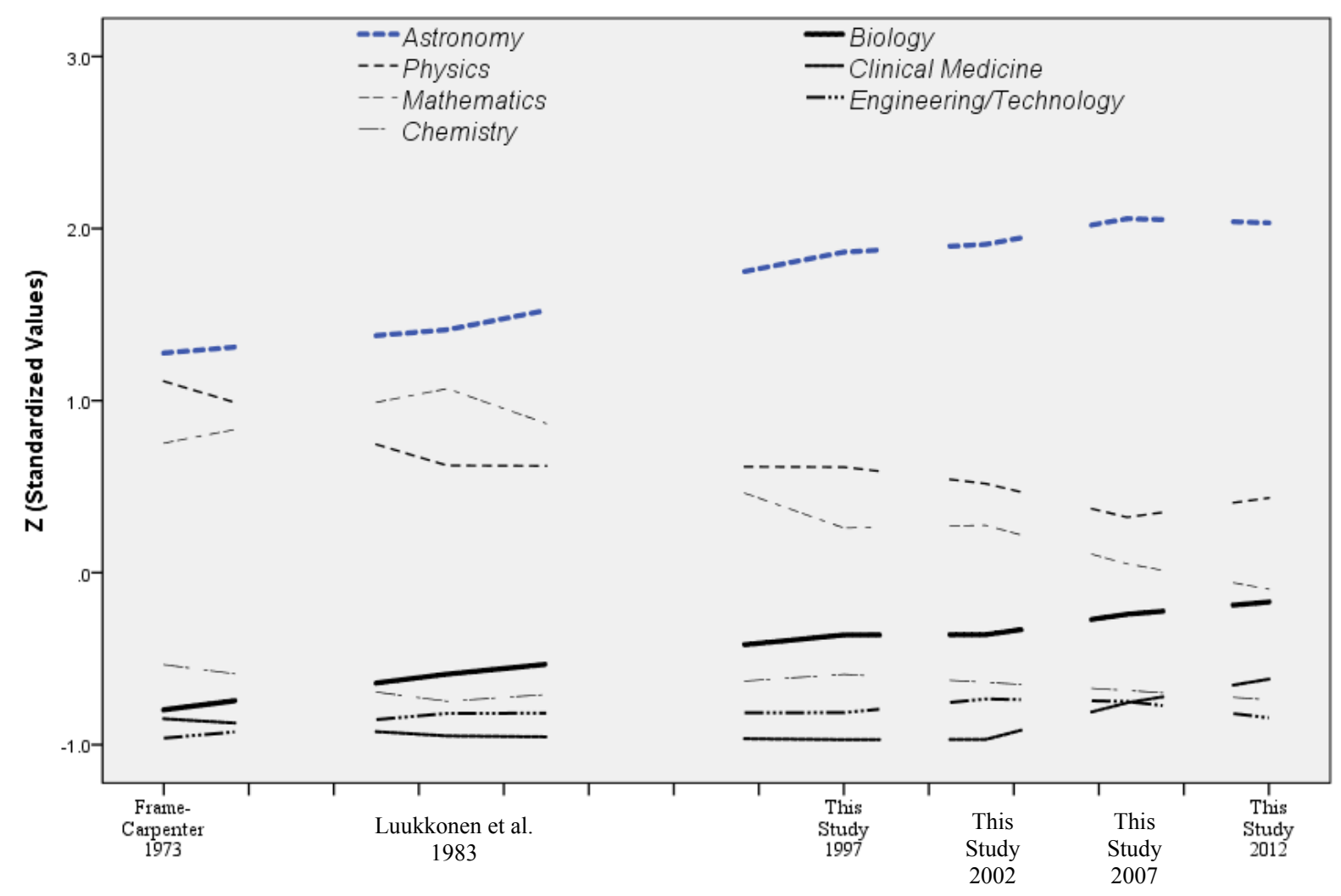

Figure 4: Patterns of international research collaboration across scientific fields

Note: Standardised Z values are obtained based on collaboration intensity. See more information in Table 2 and Table C1 in Appendix C.

By classifying all fields into two major groups, i.e. theoretical and applied sciences, Figure 5 presents the evolutionary dynamics of these binomial macro-collaboration patterns. A vital observation is the clear evolutionary convergence between pathways of theoretical and applied sciences. This convergence is even more pronounced if the outlier field of Astronomy is excluded (cf. Fig. 4). The coefficients of estimated relationships confirm a clear convergent process of collaboration patterns, with both theoretical and applied research fields approaching towards the line of zero $-Z$ standardised value ${ }^{4}$. The convergence can be further analysed by the coefficient of variation (CV), which declines constantly, both in the first case with all fields and in the second case without Astronomy (Table C2 in Appendix). The continuously decreasing variance of international research collaborations confirms the strong long-run convergent process in collaboration patterns across scientific fields.

\footnotetext{
${ }^{4}$ As indicated in the Methodology section, a zero-Z standardised value indicates that the collaboration intensity is equal to the arithmetic mean.
} 


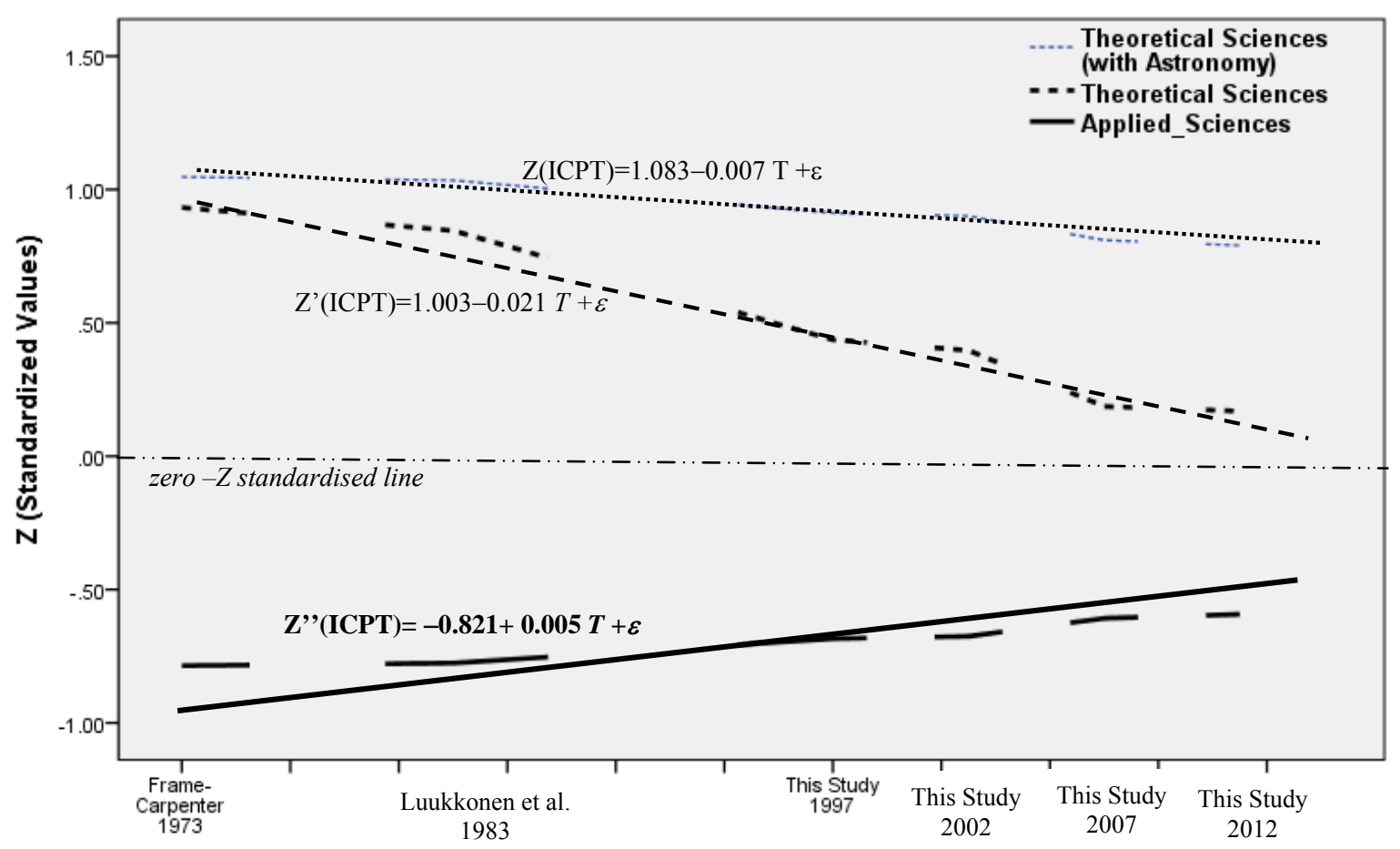

Figure 5: Convergent process of the intensity of international research collaborations between theoretical and applied sciences

Note: 1) Based on $\mathrm{Z}$ standardised values indicated in Table 2 and Table $\mathrm{C} 1$ in Appendix C.

2) Theoretical Sciences include Astronomy, Physics and Mathematics; Applied Sciences include Chemistry, Biology, Clinical Medicine and Engineering;

3) The intermittent lines of theoretical and applied sciences are based on observed data; the linear lines are estimated relationships by OLS Method.

4) $\mathrm{Z}(\mathrm{ICP})=$ Standardisation of intensity of internationally co-authored papers; $\mathrm{T}=$ time; $\varepsilon=$ Error term; significant coefficients of regression $p \leq 0.001 ; \mathrm{R}^{2}$ adj. $\geq 90 \%$. 0.001

In short, evolutionary pathways of collaborative research in different fields have a stability of structure: high collaboration intensity in theoretical research fields and lower intensity in applied ones persist over time ( $c f$. Tijssen, 2010). However, in the long run, the gap is diminishing by an on-going process of evolutionary convergence of collaboration pattern between theoretical and applied sciences.

\subsection{Explanation of convergence process and possible determinants}

The convergent process of collaboration pathways across scientific fields is due to the underlying dynamics of high growth rates in applied research fields (e.g. Medical sciences and Psychology) and lower growth rates in theoretical ones (e.g. Mathematics and Physics).

Potential determinants of this convergence of collaboration pattern, with diminishing gap between applied and theoretical sciences, can be due to: a) the increasing interdisciplinarity of current research fields, and b) very strong impact of emerging transversal disciplines (e.g. 
nanoscience and molecular biology-cf. Coccia, 2014). These two factors are closely connected. In particular, the evolution of science and technology has supported the emergence of new disciplines by either from one specific discipline or through the combination of multiple scientific fields (cf. also Jamali and Nicholas, 2010; Riesch, 2014). US National Research Council (2014) states that interdisciplinarity is a key element to spur breakthroughs by research teams with both theoretical and applied scientists. In recent decades, some new scientific fields have been established with an intrinsically interdisciplinary nature, such as nanoscience, nanotechnology, biotechnology, cognitive science, computational biology, bimolecular physics, bioengineering, etc. (cf. Jeffrey, 2003; Wang et al., 2013; Roco and Bainbridge, 2002; Van Raan, 2000; Wagner et al., 2011). Battard (2012) argues that emerging scientific fields, such as nanotechnology, involve several disciplines around the same complex problem: " laboratories are technological hubs through which scientists converge from multiple scientific backgrounds" (Battard, 2012, p. 235). In addition, traditional disciplines, such as Chemistry and Physics and Biology have been shown to be highly interdisciplinary as well (Silva et al. 2013; Boyack et al.,2005; Carley and Porter, 2012). The characteristic of interdisciplinarity in both emerging and traditional scientific fields, in the light of "big science" challenge, tends to induce converging pathways of research patterns between different scientific fields - including their patterns of international collaborations - for the solution of complex problems necessary to the modern societies and economies (cf. Coccia, 2014; Tijssen, 2010).

\section{Lessons learned and concluding observations}

The collaboration pattern of global scientific research is a topic of great interest for scholars in different disciplines (Frame and Carpenter, 1979; Beaver, 2001; Newman, 2001; Barabási et al., 2002; Tomassini and Luthi, 2007). This study provides insights on the main characteristics of the evolutionary process in international research collaborations across research fields. Some vital observed facts of this study can be summarised as follows:

1. Growing trend of international research collaboration is observed in all fields. Modern facilities such as fast transportation technology and better ICTs have boosted international research collaborations greatly.

2. General structure of international collaboration across fields has remained stable due to the nature of disciplines. Basic research fields such as Astronomy and Physics have an in- 
trinsic nature oriented to high international collaborations since they have to solve theoretical problems of universal interests for human development ( $c f$. Storer, 1970; Beaver and Rosen, 1978; Frame and Carpenter, 1979; Luukkonen et al., 1992). In addition, the high intensity of collaborations in basic science is also due to the need of sharing main scientific equipment, infrastructures and facilities to advance theoretical knowledge ( $c f$. Latour, 1987; Latour and Woolgar, 1979). Instead, some applied research fields, such as social sciences or engineering, tend to have a low intensity of international research collaboration due to their nature of aiming at local issues, which are mainly contextdependent problems (Crane, 1972; Frame and Carpenter, 1979; Luukkonen et al., 1992; Coccia, 2014).

3. Converging trajectories of collaboration patterns. This study shows a clear evolutionary convergence of international research collaborations between theoretical and applied sciences.

4. Interdisciplinarity and emerging research fields as possible determinants underlying the convergent process. The emergence of new interdisciplinary scientific fields (such as nanotechnology, biotechnology, computational biology, bimolecular physics, and bioengineering) and the high interdisciplinarity character of some traditional fields reduce the gaps of research collaboration patterns between different scientific fields. International collaboration, as one typology of research pattern, has become similar across disciplines.

In sum, despite the fast growing intensity of international collaborations in different scientific disciplines, the general collaboration structure has remained unchanged. The nature of academic disciplines is the primary factor in determining the patterns of international research collaborations. In the evolutionary process of science, however, the gap of research genres between theoretical and applied sciences has been significantly narrowed down over time. 


\section{Appendix A: Fields and subfields of publications data}

\begin{tabular}{|c|c|c|}
\hline Engineering & Biological sciences & Medical sciences (continued) \\
\hline Aerospace engineering & General biomedical research & Urology \\
\hline Chemical engineering & Miscellaneous biomedical research & Nephrology \\
\hline Civil engineering & Biophysics & Allergy \\
\hline Electrical engineering & Botany & Fertility \\
\hline Mechanical engineering & Anatomy and morphology & Geriatrics \\
\hline Metals and metallurgy & Cell biology, cytology, and histology & Embryology \\
\hline Materials engineering & Ecology & Tropical medicine \\
\hline Industrial engineering & Entomology & Addictive diseases \\
\hline Operations research and management & Immunology & Microscopy \\
\hline Biomedical engineering & Microbiology & Other life sciences \\
\hline Nuclear technology & Nutrition and dietetics & Speech/language pathology and audiology \\
\hline General engineering & Parasitology & Nursing \\
\hline Miscellaneous engineering and technology & Genetics and heredity & Rehabilitation \\
\hline Astronomy & Pathology & Health policy and services \\
\hline Chemistry & Pharmacology & Psychology \\
\hline Analytical chemistry & Physiology & Clinical psychology \\
\hline Organic chemistry & General zoology & Behavioural and comparative psychology \\
\hline Physical chemistry & Miscellaneous zoology & Developmental and child psychology \\
\hline Polymers & General biology & Experimental psychology \\
\hline General chemistry & Miscellaneous biology & Human factors \\
\hline Applied chemistry & Biochemistry and molecular biology & Social psychology \\
\hline Inorganic and nuclear chemistry & Virology & General psychology \\
\hline Physics & Medical sciences & Miscellaneous psychology \\
\hline Acoustics & Endocrinology & Psychoanalysis \\
\hline Chemical physics & Neurology and neurosurgery & Social sciences \\
\hline Nuclear and particle physics & Dentistry & Economics \\
\hline Optics & Environmental and occupational health & International relations \\
\hline Solid state physics & Public health & Political science and public administration \\
\hline Applied physics & Surgery & Demography \\
\hline Fluids and plasmas & General and internal medicine & Sociology \\
\hline General physics & Ophthalmology & Anthropology and archaeology \\
\hline Miscellaneous physics & Pharmacy & Area studies \\
\hline Geosciences & Veterinary medicine & Criminology \\
\hline Meteorology and atmospheric sciences & Miscellaneous clinical medicine & Geography and regional sciences \\
\hline Geology & Anaesthesiology & Planning and urban studies \\
\hline Earth and planetary sciences & Cardiovascular system & General social sciences \\
\hline Oceanography and limnology & Cancer & Miscellaneous social sciences \\
\hline Marine biology and hydrobiology & Gastroenterology & Science studies \\
\hline Environmental sciences & Haematology & Gerontology and aging \\
\hline Mathematics & Obstetrics and gynaecology & Social studies of medicine \\
\hline Applied mathematics & Otorhinolaryngology & \\
\hline Probability and statistics & Paediatrics & \\
\hline General mathematics & Psychiatry & \\
\hline Miscellaneous mathematics & Radiology and nuclear medicine & \\
\hline Computer sciences & Dermatology and venereal disease & \\
\hline Agricultural sciences & Orthopaedics & \\
\hline Dairy and animal sciences & Arthritis and rheumatism & \\
\hline Agricultural and food sciences & Respiratory system & \\
\hline
\end{tabular}




\section{Appendix B: Country/economy of the sample}

Argentina, Australia, Austria, Belgium, Brazil, Canada, Chile, China, Czech Republic, Denmark, Egypt, Finland, France, Germany, Greece, Hungary, India, Iran, Ireland, Italy, Israel, Japan, Mexico, New Zealand, Norway, Poland, Portugal, Russia, Saudi Arabia, Singapore, South Africa, South Korea, Spain, Sweden, Switzerland, Taiwan, The Netherlands, Turkey, United Kingdom, United States of America.

\section{Appendix C:}

Table C1: Intensity of international collaborations considering data 1997-2012

\begin{tabular}{|c|c|c|c|c|c|c|c|c|}
\hline & \multicolumn{8}{|c|}{ Intensity of internationally co-authored papers } \\
\hline Subject & $\begin{array}{c}\mathbf{1 9 9 7} \\
40 \\
\text { countries } \\
\end{array}$ & $\begin{array}{c}\mathbf{1 9 9 7} \\
11 \\
\text { countries } \\
\end{array}$ & $\begin{array}{c}2002 \\
40 \\
\text { countries } \\
\end{array}$ & $\begin{array}{c}2002 \\
11 \\
\text { countries } \\
\end{array}$ & $\begin{array}{c}2007 \\
40 \\
\text { countries } \\
\end{array}$ & $\begin{array}{c}\mathbf{2 0 0 7} \\
11 \\
\text { countries } \\
\end{array}$ & $\begin{array}{c}2012 \\
40 \\
\text { countries } \\
\end{array}$ & $\begin{array}{c}2012 \\
11 \\
\text { countries } \\
\end{array}$ \\
\hline Astronomy & 0.68 & 0.69 & 0.71 & 0.75 & 0.80 & 0.81 & 0.83 & 0.86 \\
\hline Physics & 0.48 & 0.50 & 0.52 & 0.55 & 0.53 & 0.57 & 0.62 & 0.64 \\
\hline Mathematics & 0.43 & 0.44 & 0.48 & 0.51 & 0.51 & 0.53 & 0.56 & 0.57 \\
\hline Chemistry & 0.32 & 0.31 & 0.36 & 0.38 & 0.40 & 0.43 & 0.46 & 0.49 \\
\hline Biology & 0.37 & 0.35 & 0.42 & 0.42 & 0.48 & 0.49 & 0.54 & 0.56 \\
\hline Psychology & 0.32 & 0.24 & 0.37 & 0.30 & 0.42 & 0.35 & 0.51 & 0.43 \\
\hline Clinical Medicine & 0.29 & 0.26 & 0.35 & 0.33 & 0.41 & 0.42 & 0.49 & 0.50 \\
\hline Engineering & 0.33 & 0.28 & 0.37 & 0.36 & 0.40 & 0.42 & 0.45 & 0.47 \\
\hline \multirow[t]{2}{*}{ AVERAGE } & 0.40 & 0.38 & 0.45 & 0.45 & 0.49 & 0.50 & 0.56 & 0.57 \\
\hline & \multicolumn{8}{|c|}{ Standardisation $\mathrm{Z}$} \\
\hline Subject & $\begin{array}{c}\mathbf{1 9 9 7} \\
40 \\
\text { countries } \\
\end{array}$ & $\begin{array}{c}\mathbf{1 9 9 7} \\
11 \\
\text { countries } \\
\end{array}$ & $\begin{array}{c}\mathbf{2 0 0 2} \\
40 \\
\text { countries } \\
\end{array}$ & $\begin{array}{c}2002 \\
11 \\
\text { countries }\end{array}$ & $\begin{array}{c}\mathbf{2 0 0 7} \\
40 \\
\text { countries } \\
\end{array}$ & $\begin{array}{c}\mathbf{2 0 0 7} \\
11 \\
\text { countries } \\
\end{array}$ & $\begin{array}{c}\mathbf{2 0 1 2} \\
40 \\
\text { countries } \\
\end{array}$ & $\begin{array}{c}2012 \\
11 \\
\text { countries }\end{array}$ \\
\hline Astronomy & 2.14 & 1.99 & 2.15 & 2.03 & 2.28 & 2.16 & 2.23 & 2.16 \\
\hline Physics & 0.63 & 0.75 & 0.56 & 0.65 & 0.30 & 0.47 & 0.48 & 0.57 \\
\hline Mathematics & 0.20 & 0.40 & 0.27 & 0.42 & 0.09 & 0.20 & 0.00 & 0.04 \\
\hline Chemistry & -0.66 & -0.45 & -0.73 & -0.49 & -0.73 & -0.52 & -0.79 & -0.59 \\
\hline Biology & -0.22 & -0.22 & -0.19 & -0.22 & -0.07 & -0.09 & -0.12 & -0.03 \\
\hline Psychology & -0.64 & -0.96 & -0.63 & -1.00 & -0.55 & -1.06 & -0.42 & -0.97 \\
\hline Clinical Medicine & -0.85 & -0.83 & -0.81 & -0.82 & -0.60 & -0.59 & -0.52 & -0.48 \\
\hline Engineering & -0.60 & -0.67 & -0.62 & -0.58 & -0.71 & -0.58 & -0.85 & -0.70 \\
\hline
\end{tabular}

Note: Astronomy in some studies is called Earth/Space.

Table C2: Coefficient of Variation

\begin{tabular}{lcccccc}
\hline Period of data & 1973 & 1983 & 1997 & 2002 & 2007 & 2012 \\
& $\begin{array}{c}\text { Frame and } \\
\text { Carpenter }\end{array}$ & $\begin{array}{c}\text { Luukkonen } \\
\text { et al. }\end{array}$ & $\begin{array}{c}\text { This } \\
\text { Study }\end{array}$ & $\begin{array}{c}\text { This } \\
\text { Study }\end{array}$ & $\begin{array}{c}\text { This } \\
\text { Study }\end{array}$ & $\begin{array}{c}\text { This } \\
\text { Study }\end{array}$ \\
\hline $\begin{array}{l}\text { Coefficient of Variation } \\
\text { (all fields) }\end{array}$ & 0.49 & 0.39 & 0.38 & 0.31 & 0.27 & 0.23 \\
$\begin{array}{l}\text { Coefficient of Variation } \\
\text { (without Astronomy) }\end{array}$ & 0.49 & 0.37 & 0.27 & 0.20 & 0.13 & 0.12 \\
\hline
\end{tabular}




\section{References}

Adams J. (2012) The rise of research networks, nature, Nature, Oct 18; vol. 490, n. 7420, pp. $335-6$.

Allen T.J., Tushman M. L., Lee D.M. S. (1979) Technology transfer as a function of position in the spectrum from research trough development to technical services, Academy of management journal, vol. 22, n. 4, pp. 694-708.

Barabási A. L., Jeong H., Néda Z, Ravasz E., Schubert A., Vicsek T. (2002) Evolution of the social network of scientific collaborations, Physica A, vol. 311, pp. $590-614$.

Battard (2012) Convergence and multidisciplinarity in nanotechnology: Laboratories as technological hub, Technovation, vol. 32, pp. 234-244.

Beaver deB. D. (2001) Reflections on scientific collaboration (and its study): past, present, and future, Scientometrics, vol. 52, n. 3, pp. 365-377.

Beaver deB. D., Rosen R. (1978) Studies in scientific collaboration. Pt. I, The professional origins of scientific co-authorship, Scientometrics, vol. 1, pp. 65-84.

Boyack K., Klavans, R., Borner, K. (2005) Mapping the backbone of science. Scientometrics, vol. 64 , pp. 351-374.

Bozeman B. (2004) Scientists' collaboration strategies: Implications for scientific and technical human capital, Research Policy, vol. 33, pp. 599-616.

Carley S., Porter A. L. (2012) A forward diversity index, Scientometrics, vol. 90, pp. 407427.

Coccia M. (2014) Emerging technological trajectories of tissue engineering and the critical directions in cartilage regenerative medicine, Int. J. Healthcare Technology and Management, vol. 14, n. 3, pp. 194-208.

Coccia M. (2014a) Converging scientific fields and new technological paradigms as main drivers of the division of scientific labour in drug discovery process: the effects on strategic management of the R\&D corporate change, Technology Analysis \& Strategic Management, Vol. 26, n. 7, pp. 733-749.

Crane D. (1972) Transnational Networks in Basic Science, in Robert O. Keohane, Joseph S. Nye (eds.), Transnational Relations and World Politics, Harvard University Press, Cambridge, Mass., pp. 235-251.

Cummings J. N., Kiesler S. (2005) Collaborative Research Across Disciplinary and Organizational Boundaries, Social Studies of Science, vol. 35, 5: pp. 703-722.

de Solla Price D. J. (1963) Little Science, Big Science, Columbia University Press, New York.

de Solla Price D. J. (1986) Little science, big science... and beyond, Columbia University Press, New York.

de Solla Price D., deB. Beaver D. (1966) Collaboration in an invisible college, American Psychologist, vol. 21, pp. 1011-1018.

Egghe L. (1991) Theory of collaboration and collaborative measures, Information processing \& management, vol. 27, nos. 2/3, pp. 117-202. 
Frame D. J., Narin F., Carpenter M. P. (1977) The distribution of world science, Social Studies of Science, vol. 7, n. 4, pp. 501-516.

Frame J. D. (1979) National Economic Resources and the Production of Research in Lesser Developed Countries, Social Studies of Science, vol. 9, pp. 233-246.

Frame J. D., Carpenter M. P. (1979) International research collaboration, Social Studies of Science vol. 9, pp. 481-497.

Georghiou L. (1998) Global cooperation in research, Research policy, vol. 27, pp. 611-626.

Glänzel W., De Lange C. (1997) Modelling and measuring multilateral co-authorship in international scientific collaboration. Part II. A comparative study on the extent and change of international scientific collaboration links, Scientometrics vol. 40, n. 3, pp. 605-626

Hackett E. J. (2005) Introduction to the Special Guest-Edited Issue on Scientific Collaboration, Social Studies of Science, vol. 35, 5: pp. 667-671.

Hand E. (2010) Big science' spurs collaborative trend, Nature, Jan 21; vol. 463, n. 7279, p. 282.

Inhaber H. (1977) Scientists and economic growth, Social Studies of Science, vol. 7, n. 4, pp. 517-524.

Jamali H. R., Nicholas D. (2010) Interdisciplinarity and the information-seeking behavior of scientists, Information Processing and Management, vol. 46, pp. 233-243.

Jeffrey P. (2003) Smoothing the Waters: Observations on the Process of Cross-Disciplinary Research Collaboration, Social Studies of Science, vol. 33, 4: pp. 539-562.

Jeong S., Choi J. Y., Kim J. (2011) The determinants of research collaboration modes: exploring the effects of research and researcher characteristics, Scientometrics, vol. 89, pp. 967-983.

Katz J. S., Martin B. R. (1997) What is research collaboration?, Research policy, vol. 26, pp. $1-18$.

Kuhn T. S. (1970) The Structure of Scientific Revolutions, University of Chicago Press, Chicago.

Latour B. (1987) Science in action, Harvard University Press, Cambridge, MA.

Latour B., Woolgar, S., (1979) Laboratory Life: the Social Construction of Scientific Facts. Sage, London and Beverly Hills.

Laudel G. (2001) Collaboration, creativity and rewards: Why and how scientists collaborate, International Journal of Technology Management, vol. 22, pp. 762-781.

Lee S., Bozeman B. (2005) The Impact of Research Collaboration on Scientific Productivity, Social Studies of Science, vol. 35, 5: pp. 673-702.

Luukkonen T., Persson O., Sivertsen G. (1992) Understanding patterns of international scientific collaboration, Science, Technology \& Human Values, vol. 17, n. 1, pp. 101-126.

Luukkonen T., Tijssen R.J.W., Persson O., Sivertsen G. (1993) The measurement of international scientific collaboration, Scientometrics, vol. 28, pp. 15-36.

National Science Foundation (2014) National Center for Science and Engineering Statistics http://www.nsf.gov/ (accessed November). 
Newman M. E. J. (2001) The Structure of Scientific Collaboration Networks, Proceedings of the National Academy of Sciences of the United States of America, vol. 98, n. 2, pp. 404-409.

Peters H. P. F., Van Raan A. F. J. (1989) Structuring scientific activities by co-author analysis, Scientometrics, vol. 20, pp. 235- 255.

Presser S. (1980) Collaboration and the Quality of Research, Social Studies of Science, vol. 10, 1: pp. 95-101.

Puuska H.-M., Muhonen R., Leino Y. (2014) International and domestic co-publishing and their citation impact in different disciplines, Scientometrics, vol. 98, pp. 823-839.

Riesch H. (2014) Philosophy, history and sociology of science; Interdisciplinary and complex social identities, Studies in History and Philosophy of Science, vol. 48, pp. 30-37

Roco M. C., Bainbridge W.S. (2002) Converging Technologies for Improving Human Performance: Nanotechnology, Biotechnology, Information Technology and the Cognitive Science, National Science Foundation, Arlington, VA.

Schubert A., Braun T. (1990) International collaboration in the sciences 1981-1985. Scientometrics vol. 19, pp. 3-10.

Silva F. N., Rodrigues F. A., Oliveira Jr O. N., Costa L. da F. (2013) Quantifying the interdisciplinarity of scientific journals and fields, Journal of Informetrics, vol. 7, pp. 469477.

Stephan P. E. (1996) The economics of science, Journal of Economic Literature, vol. XXXIV, September, pp. 1199-1235.

Stokes T. D., Hartley J. A. (1989) Coauthorship, social structure and influence within specialties, Social Studies of Science, vol. 19, pp. 101-125.

Storer N. W. (1970) The Internationality of Science and the Nationality of Scientists, International Social Science Journal, vol. 22 , pp. 89-104.

Thomson Reuters, SCI and SSCI (2013) http://thomsonreuters.com/products_services/science/.

Tijssen R. J.W. (2010) Discarding the 'Basic Science/Applied Science' Dichotomy: A Knowledge Utilization Triangle Classification System of Research Journals, Journal of the American Society for Information Science and Technology, vol. 61, n. 9, pp. $1842-1852$.

Tomassini M., Luthi L. (2007) Empirical analysis of the evolution of a scientific collaboration network, Physica A, vol. 385, pp. 750-764.

US National Research Council (2014) Convergence: Facilitating Transdisciplinary Integration of Life Sciences, Physical Sciences, Engineering, and Beyond-Committee on Key Challenge Areas for Convergence and Health Board on Life Sciences Division on Earth and Life Studies, The National Academies Press, Washington, D.C.

Van Leeuwen Th. N., R. J. W. Tijssen (1993) Assessing Multidisciplinary Areas of Science and Technology: A Synthetic Bibliometric Study of Dutch Nuclear Energy Research Scientometrics, vol. 26. no. 1, pp. 115-133

Van Raan A. F. J. (1988) (ed.) Handbook of quantitative studies of science and technology, Elsevier, Amsterdam. 
Van Raan A. F. J. (1998) The influence of international collaboration on the impact of research result, Scientometrics, vol. 42, n. 3, pp. 423-428.

Van Raan A. F. J. (2000) Practising interdisciplinarity. In The interdisciplinary nature of science: Theoretical framework and bibliometric-empirical approach, University of Toronto Press, Toronto, pp. 66-78.

Wagner C. S., Roessner J. D., Bobb K., Klein J. T., Boyack K. W., Keyton J., Rafols I. Börner K. (2011) Approaches to Understanding and Measuring Interdisciplinary Scientific Research (IDR): A Review of the Literature. Journal of Informetrics, vol. 5, n. 1, pp. 14-26.

Wang L., Notten A., Surpatean A. (2013) Interdisciplinary of nanoresearch fields: a keyword mining approach, Scientometrics, vol., 94, pp. 877-892.

Zitt M., Bassecoulard E., Okubo Y. (2000) Shadows of the past in international cooperation: collaboration profiles of the top five producers of science, Scientometrics, vol. 47, n. 3, pp. 627-657. 


\section{The UNU-MERIT WORKING Paper Series}

2015-01 How does firms' perceived competition affect technological innovation in Luxembourg? by Wladimir Raymond and Tatiana Plotnikova

2015-02 The effect of supplementation with locally available foods on stunting. A review of theory and evidence by Mutinta Nseluke Hambayi, Wim Groot and Nyasha Tirivayi

2015-03Ethnic divisions, political institutions and the duration of declines: A political economy theory of delayed recovery Richard Bluhm and Kaj Thomsson

2015-04 Offshoring of medium-skill jobs, polarization, and productivity effect: Implications for wages and low-skill unemployment by Ehsan Vallizadeh, Joan Muysken and Thomas Ziesemer

2015-05 Risk preference or financial literacy? Behavioural experiment on index insurance demand by Yesuf M. Awel and Théophile T. Azomahou

2015-06 Poverty persistence and informal risk management: Micro evidence from urban Ethiopia by Théophile T. Azomahou and Eleni A. Yitbarek

2015-07 Research joint ventures in an R\&D driven market with evolving consumer preferences: An evolutionary multi-agent based modelling approach by Salih Çevikarslan

2015-08 The effects of remittances on support for democracy in Africa: Are remittances a curse or a blessing? by Maty Konte

2015-09 The location strategies of multinationals from emerging countries in the EU regions by Riccardo Crescenzi, Carlo Pietrobelli and Roberta Rabellotti

2015-10 North-South FDI and Bilateral Investment Treaties by Rod Falvey and Neil FosterMcGregor

2015-11 Evolutionary convergence of the patterns of international research collaborations across scientific fields by Mario Coccia and Lili Wang 